\title{
A predictive framework and review of the ecological impacts of exotic plant invasions on reptiles and amphibians
}

Leigh J. Martin* and Brad R. Murray

Plant Functional Biology and Climate Change Cluster, Department of Environmental Sciences, University of Technology Sydney, PO Box 123, Broadway, NSW 2007, Australia

*Author for correspondence (Tel: + 6129514 8346; Fax: + 6129514 4079; E-mail:

Leigh.Martin@uts.edu.au). 


\section{ABSTRACT}

The invasive spread of exotic plants in native vegetation can pose serious threats to native faunal assemblages. This is of particular concern for reptiles and amphibians because they form a significant component of the world's vertebrate fauna, play a pivotal role in ecosystem functioning and are often neglected in biodiversity research. A framework to predict how exotic plant invasion will affect reptile and amphibian assemblages is imperative for conservation, management and the identification of research priorities. Here, we present a new predictive framework that integrates three mechanistic models. These models are based on exotic plant invasion altering: (1) habitat structure; (2) herbivory and predator-prey interactions; (3) the reproductive success of reptile and amphibian species and assemblages. We present a series of testable predictions from these models that arise from the interplay over time among three exotic plant traits (growth form, area of coverage, taxonomic distinctiveness) and six traits of reptiles and amphibians (body size, lifespan, home range size, habitat specialisation, diet, reproductive strategy). A literature review provided robust empirical evidence of exotic plant impacts on reptiles and amphibians from each of the three model mechanisms. Evidence relating to the role of body size and diet was less clear-cut, indicating the need for further research. The literature provided limited empirical support for many of the other model predictions. This was not, however, because findings contradicted our model predictions but because research in this area is sparse. In particular, the small number of studies specifically examining the effects of exotic plants on amphibians highlights the pressing need for quantitative research in this area. There is enormous scope for detailed empirical investigation of interactions between exotic plants and reptile and amphibian species and assemblages. The framework presented here and further testing of predictions will provide a basis for informing and prioritising environmental management and exotic plant control efforts. 
Key words: amphibians, reptiles, conservation, ecological impacts, exotic plants, herpetofauna, invasion, life-history traits.

\section{CONTENTS}

I. Introduction

II. Conceptual framework and mechanisms of impact

(1) Model 1: changes to habitat structure, quality and heterogeneity

(a) Theory

(b) Predictions

(c) Empirical evidence to support framework

(2) Model 2: alteration of herbivory and predator-prey interactions

(a) Theory

(b) Predictions

(c) Empirical evidence to support framework

(3) Model 3: modification of reproductive success

(a) Theory

(b) Predictions

(c) Empirical evidence to support framework

III. Management implications and future research opportunities

IV. Conclusions

V. Acknowledgements

VI. References 


\section{INTRODUCTION}

The introduction of exotic species into new regions and ecological systems poses a serious threat to biodiversity (IUCN, 2000; Millennium Ecosystem Assessment, 2005). Plant assemblages infiltrated by exotic plants often experience declines in native species richness, diversity and functioning (Braithwaite, Lonsdale \& Estbergs, 1989; Griffin et al., 1989; D'Antonio \& Vitousek, 1992; Gordon, 1998; Parker et al., 1999; Clarke, Lake \& O’Dowd, 2004). As a consequence, the establishment and invasive spread of exotic plants in native vegetation presents major challenges for the management and conservation of biodiversity.

The effects of exotic plant invasions on native plant communities have been the focus of considerable research efforts around the world. The majority of ecological impacts identified include reductions in native plant species richness and alterations to ecological function (Vitousek \& Walker, 1989; Adair \& Groves, 1998; Levine et al., 2003; Ogle, Reiners \& Gerow, 2003; Vila et al., 2006; Hejda, Pysek \& Jarošik, 2009). Sometimes, however, the diversity of plant assemblages invaded by exotic plants may be unchanged, or even show signs of increase (Sax \& Gaines, 2003; Sax, Kinlan \& Smith, 2005). Thus, invasion of native vegetation by exotic plants does not always lead to declines in native plant communities, which has important implications for the resident native animal species and assemblages.

The arrival of exotic plants in new ecosystems can affect native animal species and assemblages by modifying vegetation composition and structure. There is a growing body of research demonstrating that the incursion of exotic plants into native vegetation causes significant alterations to species richness, composition and abundance of invertebrates (Slobodchikoff \& Doyen, 1977; Griffin et al., 1989; Herrera \& Dudley, 2003; Greenwood, O’Dowd \& Lake, 2004; Ernst \& Cappuccino, 2005; Robson, Baker \& Murray, 2009). Possible mechanisms underpinning the impacts of exotic plants on invertebrate assemblages include reduced habitat complexity and unsuitability of introduced plants to native herbivores 
(Slobodchikoff \& Doyen, 1977; Herrera \& Dudley, 2003; Ernst \& Cappuccino, 2005). Like native plant assemblages, the ecological outcomes of exotic plant invasion on invertebrate communities are quite varied. As yet, however, there is no general model that can account for the range of impacts observed in invertebrate communities (but see Sax et al., 2005; Murray, Baker \& Robson, 2009).

The presence of exotic plants in native plant assemblages can have significant effects on native vertebrate inhabitants. For example, Mazzotti, Ostrenko \& Smith (1981) observed reduced abundance of three native mammal species in areas of Southern Florida (USA) occupied by the exotic trees Melaleuca quinquenervia and Casuarina equisetifolia. Despite concern, however, that exotic plant invasion will cause decline of native bird and mammal species, the current literature reveals no consistent positive, negative or neutral effects of increases in exotic plant cover within mammalian and avian assemblages (Murray et al., 2007). Furthermore, there is a conspicuous absence of a general understanding of the impacts of exotic plant invasion on reptiles and amphibians, a significant component of the world's vertebrate fauna. Given the pivotal roles of reptiles and amphibians in the functioning of ecosystems (Burton \& Likens, 1975; Gardner, 2001; Pough et al., 2004), as well as the importance of amphibians as key bioindicators of ecosystem change and biodiversity loss (Blaustein \& Wake, 1990; Vitt et al., 1990; Halliday \& Heyer, 1997; Gardner, 2001), this issue warrants critical attention.

Here, we present a framework that predicts how reptile and amphibian species and assemblages respond to invasion of their native habitats by exotic plant species. The framework integrates three mechanistic models, each linked to a set of testable predictions. Central to the models are the traits of the invading plant species (growth form, area of coverage, taxonomic distinctiveness), variation in reptile and amphibian life-history traits (body size, lifespan, home range size, habitat specialisation, diet, reproductive strategy) and interactions between these 
plant and animal traits. A key component of the framework is the explicit inclusion of the timeframe for the effects of exotic plant invasion to become detectable. This temporal element recognises that there may be a lag time before ecological effects are discernable. We also provide a comprehensive review of published empirical studies of the impacts of exotic plants on reptiles and amphibians. The aim of this review is to link empirical evidence to model predictions of the framework.

\section{CONCEPTUAL FRAMEWORK AND MECHANISMS OF IMPACT}

Animals must feed, avoid predation, tolerate or avoid abiotic stresses and reproduce (Anderson, 2007). The extent to which exotic plants affect reptiles and amphibians is determined by the influences they exert on these basic functions. Our conceptual framework considers how exotic plant and native animal traits interact to affect these functions through three mechanistic models. The models are based on exotic plant invasion altering: (1) habitat structure, quality and heterogeneity; (2) herbivory and predator-prey interactions; and (3) the reproductive success of reptile and amphibian species and assemblages (Fig. 1). How these mechanisms, which are not mutually exclusive, exert an influence on reptile and amphibian species and assemblages is directly controlled by interactions between the life-history traits of exotic plants and reptiles and amphibians. For each model, we present ecological theory that shapes its basic structure, provide a series of testable predictions and describe empirical evidence based on a literature review (Table 1).

There are often significant, negative ecological effects of exotic plants on reptiles, with a couple of exceptions (Table 1). The lack of studies on amphibians is noteworthy. As a case study for the Australian continent, we also provide lists of threatened species of Australian reptiles and amphibians identified as at risk from exotic plant invasion (Tables 2, 3). These lists indicate possible impacts of exotic plants on individual reptile and amphibian species and are 
often based on subjective assessments of experienced scientists and application of the precautionary principle (Coutts-Smith \& Downey, 2006). Exotic plants do not necessarily represent the sole threats to these species or reasons for their decline. Thus, exotic plant invasion will, in most cases, act in concert with other threats and environmental stresses.

\section{(1) Model 1: Changes to habitat structure, quality and heterogeneity}

(a) Theory

Habitat structure and spatial heterogeneity are important factors regulating the characteristics of reptile assemblages (Pianka, 1967). Changes in habitat features correspond with changes in the composition and structure of reptilian assemblages (Heatwole \& Taylor, 1987). Typically, more diverse vegetation or increased structural diversity increases the number of spatial niches available, which leads to increased reptile species richness (Heatwole \& Taylor, 1987). Spatial heterogeneity is also an important influence on within-habitat diversity of amphibians for similar reasons (Duellman \& Trueb, 1994). Changes to vegetation and habitat structure from exotic plant invasion will, thus, alter the availability of spatial niches and the suitability of habitat for individual species. The extent to which alteration of spatial niches will affect a particular species may vary according to the degree of habitat specialisation. Habitat specialists may be more sensitive to habitat modification by exotic plants than generalist species with a broader niche range. While literature on this matter is depauperate in relation to reptiles and amphibians, insect herbivore assemblages on exotic plant hosts consist of generalist rather than specialist species (Brandle et al., 2008).

Home range size is an important factor relevant to the effect of changes in habitat structure on an individual reptile or amphibian. Species with smaller home ranges will have a greater proportion of their environment modified, be less able to respond to deleterious environmental changes by relocating or avoiding unsuitable areas and will be affected at a 
lower level of exotic plant coverage, than species with large home ranges. For species with smaller home ranges, a given area of exotic plant coverage may also affect a larger number of individuals than species with larger home ranges. Equally, advantageous changes to habitat structure (e.g. increasing availability of cover) are likely to exert their influence more strongly on species with a smaller home range as less coverage is needed to provide benefit to a greater number of individuals.

Body size and home range in lizards are positively correlated (Turner, Jennrich \& Weintraub, 1969; Perry \& Garland, 2002). In this respect, body size may in part, predict sensitivity to presence and area of exotic plants. However, the relationship between body size and home range is complicated by other influences such as diet, foraging mode, sexual dimorphism and phylogenetic differences (Rose, 1982; Christian \& Waldschmidt, 1984; Perry \& Garland, 2002) and a number of studies estimating home ranges have suffered from small sample sizes (Rose, 1982). Nevertheless, influence on home range size is not the only way in which body size may be important in influencing the responsiveness of reptiles and amphibians to exotic plant incursion. Body size can also influence the sensitivity of ectotherms to changes in thermal conditions of their environment.

Thermoregulation and maintenance of body temperature within appropriate ranges for various levels of activity is a key physiological task for many ectotherms. Considerable activity may therefore be devoted to thermoregulatory behaviour and selection of appropriate microclimates (Heatwole \& Taylor, 1987). In many reptile and amphibian species this includes 'shuttling' between sun and shade or warm and cold substrates or water in order to maintain body temperature within appropriate ranges (Heatwole \& Taylor, 1987; Duellman \& Trueb, 1994; Shine, 1998). Changes to insolation and shading as a result of altered vegetation structure will have an impact on the availability and suitability of basking sites, shaded areas and the tendency of substrates to absorb and maintain heat energy. For instance, thermal conditions and 
shading directly influence habitat preferences of the scincid lizards Carlia vivax and Lygisaurus foliorum in subtropical areas of northern Australia (Singh, Smyth \& Blomberg, 2002).

Alteration of thermal conditions and shading by exotic plants is highly likely to influence the nature of reptile and amphibian assemblages. Smaller ectotherms exhibit more rapid rates of heating and cooling than larger animals (Heatwole \& Taylor, 1987; Shine, 1998). Furthermore, smaller lizards shuttle between sun and shade more frequently than do larger lizards (Bowker, 1984; Heatwole \& Taylor, 1987). There is strong evidence that smaller lizards may be more sensitive to modification of shade and basking sites brought about by exotic plants.

An emerging area of investigation is the extent to which different growth forms or functional groups of exotic plants differ in their impacts on ecological communities. Impacts are likely to be most severe where an exotic plant represents a growth form that is absent or is a minor component in the community subject to invasion (Grice, 2004). Investigation of thirteen invasive plant species in the Czech Republic revealed marked differences in their impact on species richness and evenness of invaded plant communities (Hejda et al., 2009). Severity of impact was highly specific to particular invaders and strongly influenced by the difference between the cover and height of the invader and native dominant species. By contrast, a review of the impacts of graminoid and woody invasive species showed few differences in their effects on most native plant functional groups (Mason, French \& Lonsdale, 2009).

In contrast to studies showing significant effects of exotic plants on animal assemblages, Sax (2002) found little difference in species richness and diversity of understorey plants, leaf-litter invertebrates, amphibians and birds between plantations of the exotic eucalypt (Eucalyptus globulus) and native woodland dominated by coast live oak (Quercus agrifolia) and California bay tree (Umbellularia californica). Species composition did, however, vary between exotic and native vegetation. In that system understorey plants were apparently more important in determining diversity and composition of faunal assemblages than were trees, 
providing further evidence that the impact of exotic plants may vary with growth form and structural features.

We have noted the importance of home range size in influencing the responsiveness of reptile and amphibian species to exotic plant invasion. The corollary of this is that coverage, or stand size, of exotic plants will be an important factor determining their influence on reptiles and amphibians. Larger coverage or stand size may be required to exert impacts on species with larger home range. Thus, coverage will influence both the degree of effect exerted on an individual species and the number of species affected within an assemblage.

\section{(b) Predictions}

Considering the interaction between life-history traits of reptiles and amphibians and exotic plants, and mechanisms of impact, allows us to formulate specific predictions of the response of reptile and amphibian species and assemblages to changes in habitat structure caused by the incursion of exotic plants (see the top section of Fig. 1).

Prediction 1: there will be a positive correlation between habitat diversity and/or availability of cover, such that decreases in habitat diversity and cover will lead to declines in species richness and abundance of reptiles and amphibians. Increases in habitat diversity and cover will lead to increases in reptile and amphibian abundance and species richness.

Prediction 2: smaller-bodied species, and species with smaller home ranges, will display greater sensitivity and faster response to exotic plant invasion than larger-bodied species and species with larger home ranges. The latter require a greater area of coverage of exotic plants for effects to be discernable and would be expected to show slower responses to exotic plants due to the time needed for exotic plants to spread and increase their area of coverage (see Fig. 1). Prediction 3: habitat specialists will display stronger and more rapidly detectable responses to exotic plant invasion than generalist species. 
Prediction 4: exotic plants exhibiting novel growth forms or structural features will exert stronger and more rapid influences on reptiles and amphibians via changes to habitat structure and quality, including leaf litter structure and availability of woody debris, than exotic plants that replicate existing growth forms and structural features.

Prediction 5: the degree of influence exerted on individual species and the number of species affected within an assemblage will increase with coverage of exotic plants.

\section{(c) Empirical evidence to support framework}

Avoidance of the introduced rubber vine (Cryptostegia grandiflora) occurred in Australian scincid lizards Carlia munda and Carlia pectoralis (Valentine, Roberts \& Schwarzkopf, 2007). This provides supporting evidence for prediction 1, as avoidance of introduced plants may well lead to declines in species richness and abundance. Specifically, both species avoided rubber vine leaf litter when allowed to select between rubber vine and native leaf litter in semi-natural enclosures (Valentine et al., 2007). The same investigation noted that rubber vine leaf litter was cooler at the surface than native leaf litter, supporting our hypothesis that alteration of habitat structure by exotic plants may have important impacts on thermal conditions. Similarly, there was a strong influence of exotic pine (Pinus spp.) on reptile assemblages in the tropics of northern Australia. Pine plantations were cooler and received less radiant energy than native forests. Reptile assemblages in these pine plantations comprised mostly closed-canopy rainforest species that prefer cooler, shadier habitats in contrast to surrounding native vegetation, which supported open woodland species (Mott, Alford \& Schwarzkopf, 2010). The long-term decline of the natterjack toad (Epidalea calamita) in heathland areas of Britain (Beebee, 1977) was related to overgrowth by pine (Pinus spp.), birch (Betula spp.), gorse (Ulex spp.) and bracken (Pteridium spp.) following land-use changes, reducing availability of basking sites for adult toads. 
Alteration of habitat structure, including leaf litter structure and availability of woody debris influences reptile assemblages. Griffin et al. (1989) recorded reduced abundance of reptiles in parts of inland northern Australian where the exotic tamarisk (Tamarix aphylla) had replaced native river gum (Eucalyptus camaldulensis) vegetation. Tamarisk reduced the availability of potential cover for reptiles because there were fewer dead branches and logs on the ground. In addition, branches and logs that were present on the ground lacked the thick, persistent bark of eucalypt logs. Garden et al. (2007) reported that abundance of native reptiles was positively correlated with a moderate amount of exotic plant cover in urban forest fragments in Brisbane, Australia. Low weedy vegetation provided cover for reptile species and was more important than vegetation composition in determining terrestrial reptile assemblages. Mott et al. (2010) observed that burning under pine plantations in tropical northern Australia was associated with increased species richness and abundance of reptiles when compared with unburnt pine forests. Operative environmental temperatures and radiant energy were similar in burnt and unburnt pine. Avoidance of weedy leaf litter was responsible for lower species richness and abundance of reptiles in unburnt pine and removal of weedy litter by burning produced more favourable habitat conditions for reptiles. While these studies provide strong evidence for this prediction in relation to reptiles, the relative lack of studies examining the impacts of exotic plants on amphibian species and assemblages means that evidence relating to amphibians is lacking. This highlights the pressing need for further research to identify the influence of exotic plants on habitat structure for amphibians and their assemblages.

As a preliminary test of whether small body size (prediction 2) and an insectivorous diet (see Model 2, predictions 1 and 2) are linked to the listing of reptile species as threatened by exotic plants, we performed an analysis that modelled threat status of Australian reptile species (binary response variable) as a function of body size and diet (continuous and categorical explanatory variables, respectively) using a generalized linear model (binomial 
probability distribution with a logit link function) in SPSS v.17. Our analysis of 757 species for which reliable data were available (13 threatened, 744 non-threatened) found that neither body size (Wald Chi-square $=0.0001, P=0.99)$, diet (Wald Chi-square $=2.10, P=0.35)$, nor their interaction (Wald Chi-square $=1.99, P=0.37$ ) was significantly related to threat listing. It is important to note that threatened species lists do not identify species (or individual populations) that may be affected by exotic plants but have not declined sufficiently to be classified as threatened. Nor do they identify species that may benefit from the presence of exotic plants. To address these limitations, further testing of prediction 2 is required. This should include a more comprehensive analysis of threatened species lists (i.e. at a global or multiple continent scale) and field investigations of variations in species composition between areas invaded by exotic plants and uninvaded, native vegetation. Such investigations would also allow prediction 3 to be tested.

A negative correlation was observed between per cent cover of introduced Sahara mustard (Brassica tournefortii) and abundance of fringe-toed lizards (Uma inornata) in active desert dune habitats in the Coachella Valley (Barrows \& Allen, 2010). While this provides some support for prediction 4, further studies examining multiple exotic plant species of varying growth form, structural features and stand size are required to test this prediction, as well as prediction 5, in more critical detail. Further studies specifically examining amphibians and exotic plants should be viewed as a high priority as the current paucity of such studies limits the ability to assess these predictions in relation to amphibians.

\section{(2) Model 2: alteration of herbivory and predator-prey interactions}

(a) Theory

Reptile and amphibian diets vary widely among species. Reptiles may be herbivorous, omnivorous or carnivorous, however, complete herbivory is not common (Heatwole \& Taylor, 
1987; Pough et al., 2004). Available information indicates that all adult amphibians are carnivores, however, larval diets may include plant matter, phytoplankton and aquatic invertebrates as well as amphibian eggs and larvae (Duellman \& Trueb, 1994). Dietary preferences may play an important role in determining the responsiveness of a species to exotic plant invasion.

Excluding native plant species and creating monocultural stands of exotic species represents a direct mechanism of impact on herbivores, by changing forage availability (Sax, 2002). Herbivores might well respond strongly and rapidly to the incursion of exotic plants, where this incursion either reduces availability of native plant food sources or introduces novel food. Changes to invertebrate assemblages brought about by exotic plant invasion may, in turn, exert impacts on vertebrates by altering the availability and composition of prey species for insectivores (Herrera \& Dudley, 2003; Greenwood et al., 2004). Invertebrates are an important component of the diet of many reptile and amphibian species. For example, most lizards and frogs are invertebrate predators (Vitt \& Pianka, 2007; Wells, 2007). Changes to invertebrate abundance and species richness, therefore, have the potential to exert major influences on herpetofauna - an influence likely to be exerted most strongly and rapidly in species for which invertebrates are a major component of the diet. Changes to abundance of invertebrate predators will subsequently exert impacts on species preying predominately on smaller reptiles and amphibians. Thus, indirect impacts on species consuming smaller reptiles and amphibians would be detectable later than direct impacts on insectivores.

Exotic plants may have differential effects on the availability of food for reptiles and amphibians as a function of time since introduction. For example, richness of herbivores and pest species of exotic species may increase with time since introduction (Strong, McCoy \& Rey, 1977; Frenzel, Brandle \& Brandle, 2000; Brandle et al., 2008). Longer times since invasion provide increased opportunities for native species to adapt to exploiting new hosts 
(Carpenter \& Cappuccino, 2005). Comparisons of ecological assemblages between exotic and native vegetation have also revealed a significant effect of plantation age (Sax, 2002). Specifically, species richness in older plantations compared with younger plantations more closely resembled native. In particular, species richness of mammals at several sites within Australian Pinus radiata plantations less than five years old was lower than in native forests, however sites within older plantations had species richness as high as sites within native forests (Friend, 1982). Similarly, bird diversity in seven-year-old plantations of exotic Albizia falcataria in Borneo was as high as native forests but lower in younger plantations (Mitra \& Sheldon, 1993). Such increases in species richness and diversity with the age of a stand of exotic vegetation may be due to ecological succession and differences among species in the time required to colonise these habitats (Sax, 2002).

The effect of intraspecific niche partitioning in relation to diet is important. Such intraspecific niche partitioning may be related to ontogenic shifts in diet or sexual size dimorphism (Duellman \& Trueb, 1994; Shine, 1998; Shine \& Wall, 2007; Vitt \& Pianka, 2007). Specifically, in a number of species, prey type changes with body size, as larger individuals can capture, subdue and consume larger prey, while foraging ability and strategy may also vary according to size (Shine \& Wall, 2007). For example, juveniles of some ophidian species feed on small lizards or frogs while adults consume larger mammalian prey (Shine, 1998). Thus, dietary impacts of exotic plants vary within species according to age and gender. Insect herbivore assemblages on exotic plants may be dominated by generalist species (Brandle et al., 2008), raising important questions about the role of dietary specialisation on the response of reptile and amphibian species and assemblages to exotic plants. Herbivorous lizards and tortoises often feed on a small number of plant species or particular parts of plants such as younger, less fibrous leaves (Pough et al., 2004). Replacement of these specialised food sources will have a direct and rapid impact on specialised herbivore species. Specialist insect 
predators would also be more vulnerable to reductions in species richness and abundance of insect herbivores, as only small changes in plant composition may be required to cause the reduction or loss of specific foods.

Home range and body size may also influence the extent to which an individual reptile or amphibian will be affected by changes to food availability due to incursion of exotic plants. Species with smaller home ranges cannot avoid areas with diminished forage, and, thus, less forage coverage may affect more individuals. Advantageous changes to habitat for some reptile and amphibian species are likely to occur earlier in species with small home ranges. Here, less cover is needed to benefit more individuals.

Reptiles and amphibians are important prey items for a wide range of vertebrate predators as well as predatory arthropods (Duellman \& Trueb, 1994; Shine, 1998; Wells, 2007). Changes to habitat structure may increase or decrease the vulnerability of reptiles and amphibians to predation by altering the availability of cover and refuge sites. Furthermore, small reptiles and amphibians are more likely to be easy prey than larger animals for predators. Thus, the effects of structural changes to habitat by exotic plants will interact with animal body size. In addition, novel growth forms and structural features of exotic plants are likely to exert the strongest impact on the vulnerability of reptiles and amphibians to predation as they will produce the greatest change in habitat structure.

There is a growing body of evidence indicating that taxonomically distinct exotic plants (compared with native vegetation) will have stronger influences on the abundance and richness of herbivorous invertebrates. In particular, taxonomically distinct or isolated exotic plant species are likely to have reduced herbivore abundance and richness (Frenzel et al., 2000; Agrawal \& Kotanen, 2003; Brandle et al., 2008).

(b) Predictions 
From these theoretical considerations, we derive a number of predictions regarding the response of reptile and amphibian species and assemblages to altered herbivory and predator/prey interactions by exotic plants (see central section of Fig. 1).

Prediction 1: responses to changes in herbivory and predator-prey interactions will be stronger and detectable earlier in small-bodied and small-home-range species. Species with large body size and large home range will be less responsive to invasion and be affected more slowly. Prediction 2: response to alteration of the availability of forage will be strongest and detectable earliest in herbivorous and insectivorous species, especially if coupled with even finer dietary specialisation. Dietary generalist species and species that prey on vertebrates will respond more slowly.

Prediction 3: dietary variation due to ontogenic shifts and/or sexual size dimorphism will have differential impacts within a population. While long-term viability of a population may be compromised, this may not be readily detected within the limitations of short-term fauna survey and monitoring programs.

Prediction 4: exotic plants with novel growth forms and structural features will exert stronger and more rapidly detectable influences on herbivory and predator/prey relationships than exotic plants that are similar to native plants.

Prediction 5: taxonomically distinct exotic plants, compared with native vegetation, will exert stronger influences on the availability of forage for insectivores.

Prediction 6: larger coverage of exotic plants will equate to stronger influences on feeding ecology of reptiles and amphibians and more species will be affected.

Prediction 7: species richness and/or abundance of reptiles and amphibians may increase over time if the abundance and diversity of invertebrates increases. This requires the existence of remnant reptile or amphibian populations in the affected area or colonisation from nearby 
populations. The effect would be observed in insectivores before any detectable response in species preying mainly upon reptiles and amphibians.

\section{(c) Empirical evidence to support framework}

Evidence to support predictions 1 and 2 is provided by the avoidance of introduced rubber vine (Cryptostegia grandiflora) by the scincid lizards Carlia munda and Carlia pectoralis in northern Australia (Valentine et al., 2007). These are small-bodied (snout-vent length 44-52 mm) insectivorous lizards occurring in forest litter (Wilson \& Swan, 2008). Rubber vine litter contained significantly different arthropod taxa than native leaf litter, with fewer preferred prey items of C. munda and C. pectoralis. In addition, rubber vine leaves were a different shape than the elongate native leaf litter, providing less suitable cover with potentially decreased camouflage. Reduced reptile richness was associated with declines in arthropod abundance in weed-infested habitat in northern Australia (Griffin et al., 1989).

Incursion of Japanese knotweed (Fallopia japonica) into foraging areas adjacent to wetlands has reduced the foraging efficiency of frogs (Rana clamitans) in New York (Maerz, Blossey \& Nuzzo, 2005). Frogs confined to areas invaded by Japanese knotweed for $38 \mathrm{~h}$ showed significant declines in mass compared to frogs confined to uninvaded areas. Invasion by Japanese knotweed was associated with significant changes in vegetation structure and composition and invasion degraded terrestrial habitat quality for frogs by reducing arthropod abundance. Analysis of body size and diet of Australian reptiles (see Section II.1) did not identify any clear-cut link between listing as threatened by exotic plants and diet, or body size and diet combined. More comprehensive analysis of the life-history traits of species threatened by exotic plants and field investigations are required to test these predictions thoroughly. 
The relatively small number of investigations of exotic plant impacts on reptiles and amphibians provide limited evidence for predictions 3-7. Testing of predictions 3 and 4 will require detailed investigations of variations in species composition, population dynamics and diets of reptile and amphibian communities between areas invaded by exotic plants and uninvaded, native vegetation. Such investigations would also test predictions 1 and 2 further. Studies examining multiple exotic plant species of varying taxonomic distinctiveness, growth form, structural features and stand ages are required to test predictions 5-7.

\section{(3) Model 3: modification of reproductive success}

(a) Theory

Exotic plant invasion may restrict access to oviposition sites for reptiles and amphibians and alter conditions for the incubation and growth of embryos and larval offspring. The extent to which vegetation changes from exotic plants affect reproduction of reptiles and amphibians will be influenced by the nature of the exotic species and the reproductive biology of the reptile and amphibian species. In particular, viviparous species should be less susceptible to this effect, as gravid females do not require access to oviposition sites and can exert greater control over incubation temperatures by thermoregulating (Heatwole \& Taylor, 1987). Incubation temperatures can influence the growth and development of reptilian embryos, including sex determination. Growth and differentiation of amphibian larvae are also temperature dependent (Wells, 2007).

Oviparous and viviparous modes of reproduction represent opposite ends of a continuum, with variations among species in the developmental stages of embryos at the time of oviposition (Heatwole \& Taylor, 1987; Shine, 1998). Also, both modes of reproduction may be present in different parts of the ranges of some squamate species (Shine, 1998). Vulnerability to inhibition of embryonic development and biasing of sex ratios may therefore 
vary among species (or populations) depending on the degree of embryonic development at oviposition. Thus, species which exhibit oviposition immediately following ovulation such as chelonians, crocodilians and some squamates (Heatwole \& Taylor 1987) would be most vulnerable and viviparous species least vulnerable.

A higher proportion of viviparous species occur in colder habitats (Shine, 1985a, $b$, 1998) and some cold-climate areas contain only viviparous species (Shine, 1998). Viviparity in amphibians is also one of several reproductive strategies that have allowed them to occupy montane environments (Duellman \& Trueb, 1994). Thus, interference with oviposition by exotic plants will affect fewer species and exert less influence on the structure of reptile and amphibian assemblages in colder climates.

Parental transport of eggs, tadpoles and froglets occurs in a number of anuran species (Duellman \& Trueb, 1994; Wells, 2007). Parental transport may confer similar advantages to viviparity in reducing vulnerability of frogs to altered thermal conditions. Adults can avoid unfavourable conditions and select sites that are independent of oviposition locations. Species with parental transport would be less likely to show impacts from exotic plants on reproductive success compared with species without parental transport.

Temperature sensitivity to sex determination will play a role in the sensitivity of reptile and amphibian species to changes in thermal conditions for eggs and larvae linked to exotic plant invasion. As with other vertebrates, sex-determination mechanisms in reptiles and amphibians may be classified as genotypic sex determination (GSD) or environmental sex determination (ESD) (Bull, 1983; Hayes, 1998; Shine, Elphick \& Donnellan, 2002; Quinn et al., 2007). ESD, where temperature at the time of embryonic development is the determining environmental factor, may also be classified as temperature-dependent sex determination (TSD) (Quinn et al., 2007). Generally, amphibians have GSD (Wallace, Badawy \& Wallace, 1999), but TSD has been observed in many reptile species, particularly those lacking 
heteromorphic sex chromosomes such as crocodilians, chelonians and some squamates (Heatwole \& Taylor, 1987). Species exhibiting TSD will, therefore, be vulnerable to biasing of sex ratios due to altered incubation conditions.

Exotic plant invasion is more likely to affect species with a narrow range of oviposition sites than those capable of utilising a broader range of sites. Some anuran species are highly plastic in their choice of oviposition sites, while others have more specific requirements (Wells, 2007). This effect will be compounded for species or populations that employ communal nesting and that reuse nesting sites each breeding season. For instance, communal nesting in the Australian elapid Demansia psammophis can involve in excess of 500 eggs (the product of almost 100 females) at a single site, along with many egg shells from previous years (Shine, 1998). The loss or reduced suitability of such communal nesting sites could have a significant impact on local populations of these species.

The life spans and generation times of reptiles and amphibians will interact with exotic plant invasion. Loss of incubation sites for short-lived, early maturing species, where failure of a single breeding season may cause a severe reduction in the population (Heatwole \& Taylor, 1987) will produce stronger and more rapidly detectable population declines than longer lived and later maturing species, in which adults may persist despite reduced reproductive success. In addition, changes to the accessibility, suitability and number of oviposition sites due to increased cover and overshadowing by exotic plants will be more noticeable in exotic plants with novel growth forms or structural features.

\section{(b) Predictions}

We provide predictions of the impact of exotic plants on reptile and amphibian reproduction (see bottom section of Fig. 1). 
Prediction 1: incursion of exotic plants into native vegetation will influence the abundance and richness of reptiles and amphibians by restricting access to oviposition sites and altering incubation and growth of larval offspring.

Prediction 2: these impacts will be more substantial and rapid in species whose reproductive strategies include oviparity, lack of parental transport of eggs, larval young and/or froglets, strong influence of temperature in sex determination, short life span, short generation times and a narrow range of oviposition sites. Traits such as viviparity, parental transport, longer life span and generation times, genotypic sex determination and plasticity in oviposition sites will correspond to weaker and less rapidly detectable impacts.

Prediction 3: exotic plants will have less impact on reptile and amphibian reproduction in coldclimate areas where a higher proportion of viviparous species are likely to occur.

Prediction 4: exotic plants with novel growth form or structural features will exert stronger and more rapid effects on reptiles and amphibians by changing thermal conditions, compared with exotic plants that are similar to existing growth forms and structural features.

Prediction 5: increasing coverage of exotic plants will be positively correlated with increasing impacts on the reproduction of individual species and the number of species affected within an assemblage.

\section{(c) Empirical evidence to support framework}

There is strong support from the literature for prediction 1. Invasion of riparian areas by an exotic plant Chromoleana odorata prompted female Nile crocodiles (Crocodylus niloticus) in South Africa to abandon digging egg chambers when fibrous root mats were encountered (Leslie \& Spotila, 2001). Further, soil temperatures in sites shaded by Chromoleana odorata were cooler than those of unshaded sites, potentially creating biased sex ratios of offspring or completely preventing embryonic development. Interference with nesting of the American 
crocodile (Crocodylus acutus) and sea turtles also occurs in parts of south-eastern Florida subject to incursion of the exotic Casuarina equisetifolia (Austin, 1978).

A similar impact of exotic vegetation on nesting sites has been identified for the endangered Mary River turtle (Elusor macrus) in Queensland, Australia with exotic plants such as lantana (Lantana camara), para grass (Urochloa mutica) and various species of thistle (family Asteraceae) blocking access to nesting sites (Tucker, 1999; Department of Environment, Water, Heritage and the Arts, 2009). Destruction of eggs by penetration of couch grass roots (Cynodon sp.) has also been identified at nesting sites (van Kampen, Emerick \& Parkes, 2003; Department of Environment, Water, Heritage and the Arts, 2009).

Decline of the natterjack toad (Epidalea calamita) in Britain has been linked to vegetation change causing reduced suitability of breeding ponds (Beebee, 1977).

Overshadowing and cooling from vegetation change contributed to the decline. Detailed investigations of the effect of shading of breeding ponds by exotic plants on the growth and maturation of amphibian eggs and larvae are also required to test this prediction further in relation to amphibians. The studies described above also provide examples of impacts on oviparous species (prediction 2), however, further investigations are required to test this prediction. Specifically, detailed comparisons of assemblages between invaded and uninvaded areas are required to examine whether there any consistent differences in the reproductive traits of species present. Testing of prediction 3 will require investigation across a wide range of climatic regimes to determine whether impacts are exerted differentially between warm- and cold-climate areas. Studies examining multiple exotic plant species of varying growth form, structural features and stand size are required to test predictions 4 and 5. 
Control and removal of exotic plant species are important aspects of many conservation programs. It is important, therefore, that such efforts be informed by the best available scientific knowledge of the impacts of exotic plants and the efficacy of removal strategies. The effects of growth form and structural features, stand age and spatial scale of exotic vegetation on ecological assemblages have important implications for conservation efforts, in particular for determining priorities for exotic plant removal and control programs. In the absence of detailed knowledge of these effects it is difficult to determine whether efforts and funding should be focused on removing older, established and larger stands of exotic vegetation, or preventing new stands from establishing and quickly removing exotic vegetation before severe impacts occur. Indeed, removal may have more dire consequences than leaving exotic species where they are. It is also difficult to predict which exotic plant species are most likely to produce undesirable effects and should be prioritised for management and control efforts. The framework presented here provides testable predictions of the impacts of exotic plants on reptiles and amphibians and the exotic plant traits most likely to produce these impacts.

Exotic species in both terrestrial and marine environments rapidly establish interactions with other species, raising questions as to whether it is possible to restore pre-invasion biota and ecology (Vermeij, 1996). Furthermore, care must be exercised in choosing control methods to avoid causing further deleterious impacts as certain methods may affect the ecology of the invaded community (Sakai et al., 2001). For example, control of the exotic vine Clematis vitalba in the North Island of New Zealand using a combination of mechanical removal, herbicides and sheep grazing can be as damaging to a site as the exotic vegetation itself (Ogle et al., 2000). Use of chemical sprays for weed control has been listed as a threat to a number of amphibian species including green and golden bell frogs (Litoria aurea) and the spotted tree frog (Litoria spenceri) (Department of Environment and Climate Change, 2009; Department of Environment, Water, Heritage and the Arts, 2009). Exotic plant removal without a revegetation 
plan may also result in soil disturbance or re-invasion by the same or other exotic species (D'Antonio \& Meyerson, 2002). This has clear implications for exotic plant removal and control strategies such as bush regeneration. It is, therefore, important to investigate further the effects of exotic plant removal on ecological systems.

There has been little attention given to the effects of management, control and removal of exotic plant species on reptiles and amphibians, however, removal of Chromoleana odorata from riparian areas increases the use of potential nesting sites by the Nile crocodile (Crocodylus niloticus) (Leslie \& Spotila, 2001). There is a need for more detailed investigation of these factors. Specifically, studies involving multiple exotic plant species of varying growth forms, stand age and size as well as examination of the efficacy of management and control efforts would make valuable contributions to the understanding of the effect of exotic plants on reptiles and amphibians and the conservation of biodiversity.

\section{CONCLUSIONS}

(1) There are three mechanisms by which exotic plants can influence reptile and amphibian species and assemblages. These are changes to: (1) habitat structure; (2) herbivory and predator-prey interactions; and (3) reproductive success.

(2) Interactions between exotic plant and reptile and amphibian traits will determine the extent to which each of these mechanisms operate and the impacts on herpetofauna.

(3) There is limited evidence in the literature to support predictions that small-bodied, insectivorous and oviparous reptiles and amphibians will display the strongest response to invasion of exotic plants into native vegetation, however, further investigations are needed to test these predictions thoroughly.

(4) Evidence for model predictions is stronger for reptiles than for amphibians, in part due to the limited number of studies considering the effects of exotic plants on amphibians. There is 
an urgent need for quantitative research to test predictions in relation to amphibians and to increase knowledge of the impacts of exotic plants on amphibian species and assemblages.

(5) Further investigation is required to determine the importance of habitat and dietary specialisation and sex-determination mechanisms in reptiles and amphibians, and the influences of exotic plant growth form, stand age, coverage as well as taxonomic distinctiveness from native vegetation.

\section{ACKNOWLEDGEMENTS}

We thank Megan Phillips, Tom Smykowski and an anonymous reviewer for helpful comments on earlier drafts of the manuscript. We also thank Lin Schwarzkopf for helpful advice and for providing an unpublished manuscript for inclusion in this review.

\section{REFERENCES}

ADAIR, R. J. \& GROVES, R. H. (1998). Impact of environmental weeds on biodiversity: a review and development of a methodology. Environment Australia, Australian Government, Canberra.

AGRAWAL, A. A. \& KOTANEN, P. M. (2003). Herbivores and the success of exotic plants: a phylogentically controlled experiment. Ecology Letters 6, 712-715.

ANDERSON, R. A. (2007). Food acquisition modes and habitat use in lizards: questions from an integrative perspective. In Lizard Ecology. The Evolutionary Consequences of Foraging Mode (eds S. M. Reilly, L. D. McBrayer \& D. B. Miles), pp 450-490. Cambridge University Press, Cambridge.

AUSTIN, D. F. (1978). Exotic plants and their effects in southeastern Florida. Environmental Conservation 5, 25-34. 
BARROWS, C.W. \& ALLEN, M.F. (2010). Patterns of occurrence of reptiles across a sand dune landscape. Journal of Arid Environments 24, 186-192.

BEEBEE, T. J. C. (1977). Environmental change as a cause of natterjack toad (Bufo calamita) declines in Great Britain. Biological Conservation 11, 87-102.

BLAUSTEIN, A. R. \& WAKE, D. B. (1990). Declining amphibian populations: a global phenomenon. Trends in Ecology and Evolution 5, 203-204.

BOWKER, R. G. (1984). Precision of thermoregulation of some African lizards. Physiological Zoology 57, 401-412.

BRAITHWAITE, R. W., LONSDALE, W. M. \& ESTBERGS, J. A. (1989). Alien vegetation and native biota in tropical Australia: the impact of Mimosa pigra. Biological Conservation 48, 189-210.

BRANDLE, M., KUHN, I., KLOTZ, S., BELLE, C. \& BRANDLE, R. (2008). Species richness of herbivores on exotic host plants increases with time since introduction of the host. Diversity and Distributions 14, 908-915.

BULL, J. J. (1983). Evolution of Sex Determining Mechanisms. Benjamin/Cummings, Menlo Park.

BURTON, T. M. \& LIKENS, G. E. (1975). Salamander populations and biomass in the Hubbard Brook experimental forest, New Hampshire. Copeia 1975, 541-546.

CARPENTER, D. \& CAPPUCCINO, N. (2005). Herbivory, time since introduction and the invasiveness of exotic plants. Journal of Ecology 93, 315-321.

CHRISTIAN, K., A. \& WALDSCHMIDT, S. (1984). The relationship between lizard home range and body size: a reanalysis of the data. Herpetologica 40, 68-75.

CLARKE, C., LAKE, P. S. \& O'DOWD, D. J. (2004). Ecological impacts on aquatic macroinvertebrates following upland stream invasion by a ponded pasture grass 
(Glyceria maxima) in southern Australia. Marine and Freshwater Research 55, 709713.

COGGER, H. G. (2000). Reptiles and Amphibians of Australia. 6th edn. Reed New Holland, Sydney.

COUTTS-SMITH, A. \& DOWNEY, P. (2006). Impact of weeds on threatened biodiversity in New South Wales. CRC for Australian Weed Management Technical Series no. 11. CRC for Australian Weed Management, Adelaide.

D'ANTONIO, C. D. \& MEYERSON, L. A. (2002). Exotic plant species as problems and solutions in ecological restoration: a synthesis. Restoration Ecology 10, 703-713.

D'ANTONIO, C. M. \& VITOUSEK, P. M. (1992). Biological invasions by exotic grasses, the grass/fire cycle and global change. Annual review of Ecological and Systematics 23, 6387.

DEPARTMENT OF ENVIRONMENT AND CLIMATE CHANGE (2009). New South Wales Threatened Species Website. Department of Environment and Climate Change, NSW Government, Sydney. [www.threatenedspecies.environment.nsw.gov.au] Accessed 26 February 2009.

DEPARTMENT OF ENVIRONMENT, WATER, HERITAGE AND THE ARTS (2009). Species Profile and Threat Database. Australian Government, Canberra. [www.environment.gov.au/cgi-bin/sprat.pl] Accessed 26 February 2009.

DUELLMAN, W. E. \& TRUEB, L. (1994). Biology of Amphibians. 2nd edn. Johns Hopkins University Press, Baltimore and London.

ERNST, C. M. \& CAPPUCCINO, N. (2005). The effect of an invasive alien vine, Vincetoxicum rossicum (Asclepiadaceae), on arthropod populations in Ontario old fields. Biological Invasions 7, 417-425. 
FISCHER, J., LINDENMAYER, D. B. \& COWLING, A. (2003). Habitat models for the four fingered skink (Carlia tetradactyla) at the microhabitat and landscape scale. Wildlife Research 30, 495-504.

FRENZEL, M., BRANDLE, M. \& BRANDLE, R. (2000). The colonization of alien plants by phytophagous insects. In Proceedings IAVS Symposium pp. 223-225. Opulus Press, Uppsala.

FRIEND, G. R. (1982). Mammal populations in exotic pine plantations and indigenous eucalypt forests in Gippsland, Victoria. Australian Journal of Forestry 45, 3-18.

GARDEN, J. G., MCALPINE, C. A., POSSINGHAM, H. P. \& JONES, D. N. (2007). Habitat structure is more important than vegetation composition for local-level management of native terrestrial reptile and small mammal species living in urban remnants: A case study from Brisbane, Australia. Austral Ecology 32, 669-685.

GARDNER, T. (2001). Declining amphibian populations: a global phenomenon. Animal Biodiversity and Conservation 24.2, 25-44.

GORDON, D. R. (1998). Effects of invasive, non-indigenous plant species on ecosystem processes: lessons from Florida. Ecological Applications 8, 975-989.

GREENWOOD, H., O'DOWD, D. J. \& LAKE, P. S. (2004). Willow (Salix x rubens) invasion of the riparian zone in south-eastern Australia: reduced abundance and altered composition of terrestrial arthropods. Diversity and Distributions 10, 485-492.

GRICE, A. C. (2004). Weeds and the monitoring of biodiversity in Australian rangelands. Austral Ecology 29, 51-58.

GRIFFIN, G. F., SAFFORD SMITH, D. M., MORTON, S. R., ALLAN, G. E. \& MASTERS, K. A. (1989). Status and implications of the invasion of tamarisk (Tamarix aphylla) on the Finke River, Northern Territory, Australia. Journal of Environmental Management 29, 297-315. 
HADDEN, S. A. \& WESTBROKE, M. E. (1996). Habitat relationships of the herpetofauna of remnant buloke woodlands of the Wimmera Plains, Victoria. Wildlife Research 23, 363372.

HALLIDAY, T. R. \& HEYER, W. R. (1997). Are amphibian populations disappearing?: a task force status report 1996-1997. The Boreal Dip Net 2, 2-6.

HAYES, T. B. (1998). Sex determination and primary sex differentiation in amphibians: genetic and developmental mechanisms. The Journal of Experimental Zoology 281, 373-399.

HEATWOLE, H. F. \& TAYLOR, J. (1987). Ecology of Reptiles. Surrey Beatty \& Sons, Chipping Norton.

HEJDA, M., PYSEK, P. \& JAROŠIK, V. (2009). Impact of invasive plants on the species richness, diversity and composition of invaded communities. Journal of Ecology 97, 393-403.

HERRERA, A. M. \& DUDLEY, T. L. (2003). Reduction in riparian arthropod abundance and diversity as a consequence of giant reed (Arundo donax) invasion. Biological Invasions 5, $167-177$.

IUCN (2000). IUCN Guidelines for the Prevention of Biodiversity Loss Caused by Alien Invasive Species. Species Survival Commission, Invasive Species Specialist Group, IUCN, Switzerland.

JELLINEK, S., DRISCOLL, D. A. \& KIRKPATRICK, J. B. (2004). Environmental and vegetation variables have a greater influence than habitat fragmentation in structuring lizard communities in remnant urban bushland. Austral Ecology 29, 294-304.

LESLIE, A. J. \& SPOTILA, J. R. (2001). Alien plant threatens Nile crocodile (Crocodylus niloticus) breeding in Lake St. Lucia, South Africa. Biological Conservation 98, 347355. 
LEVINE, J. M., VILA, M., D'ANTONIO, C. M., DUKES, J. S., GRIGULIS, K. \& LAVOREL, S. (2003). Mechanisms underlying the impacts of exotic plant invasions. Proceedings of the Royal Society of London B 270, 775-781.

MAERZ, J. C., BLOSSEY, B. \& NUZZO, V. (2005). Green frogs show reduced foraging success in habitats invaded by Japanese knotweed. Biodiversity and Conservation 14, 2901-2911.

MASON, T. J., FRENCH, K. \& LONSDALE, W. M. (2009). Do graminoid and woody invaders have different effects on native plant functional groups? Journal of Applied Ecology 46, 426-433.

MAZZOTTI, F. J., OSTRENKO, W. \& SMITH, A. T. (1981). Effects of the exotic plants Melaleuca quinquenervia and Casuarina equisetifolia on small mammal population in the eastern Florida Everglades. Florida Scientist 44, 65-71.

MILLENNIUM ECOSYSTEM ASSESSMENT (2005). Millennium Ecosystem Assessment. Ecosystems and Human Well-being: Biodiversity Synthesis. World Resources Institute, Washington DC.

MITRA, S. S. \& SHELDON, F. H. (1993). Use of an exotic tree plantation by Bornean lowland forest birds. The Auk 110, 529-540.

MOTT, B., ALFORD, R.A. \& SCHWARZKOPF, L. (2010). Tropical reptiles in pine forests: assemblage responses to plantations and plantation management by burning. Forest Ecology and Management 259, 916-925.

MURRAY, B. R., BAKER, A. C. \& ROBSON T. C. (2009). Impacts of the replacement of native woodland with exotic pine plantations on leaf-litter invertebrate assemblages: a test of a novel framework. International Journal of Ecology 2009, 1-6.

MURRAY, B. R., DICKMAN, C. R., ROBSON, T., HAYTHORNTHWAITE, A., CANTLAY, A. J., DOWSETT, N. \& HILLS, N. (2007). Effects of exotic plants in native vegetation 
on species richness and abundance of birds and mammals. In Pest or Guest: the zoology of overabundance (eds D. Lunney, E. Peggy., P. Hutchings \& S. Burgin.), pp. 216-221. Royal Zoological Society of New South Wales, Mosman.

OGLE, C. C., LA COCK, G. D., ARNOLD, G. \& MICKELSON, N. (2000). Impact of an exotic vine Clematis vitalba (F.Ranunculacae) and of control measures on plant biodiversity in indigenous forest, Taihape, New Zealand. Austral Ecology 25, 539-551.

OGLE, S. M., REINERS, W. A. \& GEROW, K. G. (2003). Impacts of exotic annual brome grasses (Bromus spp) on ecosystem properties of northern mixed grass prairie. American Midland Naturalist 149, 46-58.

PARKER, I. M., SIMBERLOFF, D., LONSDALE, W. M., K., G., WONHAM, M., KARIEVA, P. M., WILLIAMSON, M. H., VON HOLLE, B., MOYLE, P. B., BYERS, J. E. \& GOLDWASSER, L. (1999). Impact: toward a framework for understanding the ecological effects of invaders. Biological Invasions 1, 3-19.

PERRY, G. \& GARLAND, T. (2002). Lizard home ranges revisited: effects of sex, body size, diet, habitat and phylogeny. Ecology 83, 1870-1885.

PIANKA, E. R. (1967). On lizard species diversity: North American flatland deserts. Ecology 48, 333-351.

POUGH, H. F., ANDREWS, R. M., CRUMP, M. L., SAVITKY, A. H. \& WELLS, K. D. (2004). Herpetology. 3rd edn. Pearson Prentice Hall, Upper Saddle River.

QUINN, A. E., GEORGES, A., DARRE, S. D., GUARINO, F., EZAZ, T. \& MARSHALL GRAVES, J. A. (2007). Temperature Sex reversal Implies Sex gene Dosage in a Reptile. Science 361, 411.

ROBSON, T. C., BAKER, A. C. \& MURRAY, B. R. (2009). Differences in leaf-litter invertebrate assemblages between radiata pine plantations and neighbouring native eucalypt woodland. Austral Ecology 34, 368-376. 
ROSE, B. (1982). Lizard home ranges: methodology and functions. Journal of Herpetology 16, 253-269.

SAKAI, A. K., ALLENDORF, F. W., HOLT, J. S., LODGE, D. M., MOLOFSKY, J., WITH, K. A., BAUGHMANN, S., CABIN, R. J., COHEN, J. E., ELLSTRAND, N. C., MCCAULEY, D. E., O'NEIL, P., PARKER, I. M., THOMPSON, J. N. \& WELLER, S. G. (2001). The population biology of invasive species. Annual review of Ecological and Systematics 32, 305-332.

SAX, D. F. (2002). Equal diversity in disparate species assemblages: a comparison of native and exotic woodlands in California. Global Ecology \& Biogeography 11, 49-57.

SAX, D. F. \& GAINES, S., D. (2003). Species diversity: from global decreases to local increases. Trends in Ecology and Evolution 18, 561-566.

SAX, D. F., KINLAN, B. P. \& SMITH, K. F. (2005). A conceptual framework for comparing species assemblages in native and exotic habitats. Oikos 108, 457-464.

SHINE, R. (1985a). The evolution of viviparity in reptiles: an ecological analysis. In Biology of the Reptilia (eds G. Gans \& F. Billet), pp. 605-694. Wiley-Interscience, New York.

SHINE, R. (1985b) The reproductive biology of Australian reptiles: A search for general patterns. In Biology of Australasian Frogs and Reptiles (eds G. Grigg, R. Shine \& H. Ehmann), pp. 297-303. Surrey Beatty \& Sons, Chipping Norton.

SHINE, R. (1998). Australian snakes: A natural history. Revised edn. Reed New Holland, Sydney.

SHINE, R., ELPHICK, M. J. \& DONNELLAN, S. (2002). Co-occurrence of multiple, supposedly incompatible modes of sex determination in a lizard population. Ecology Letters 5, 486-489.

SHINE, R. \& WALL, M. (2007). Why is intraspecific niche partitioning more common in snakes than in lizards? In Lizard Ecology. The Evolutionary Consequences of Foraging 
Mode (eds S. M. Reilly, L. D. McBrayer \& D. B. Miles), pp 173-208. Cambridge University Press, Cambridge.

SINGH, S., SMYTH, A.K. \& BLOMBERG, S.P. (2002). Thermal ecology and structural habitat use of two sympatric lizards (Carlia vivax and Lygisaurus foliorum) in subtropical Australia. Austral Ecology 27, 616-623.

SLOBODCHIKOFF, C. N. \& DOYEN, J. T. (1977). Effects of Ammophila arenariai on sand dune arthropod communities. Ecology 58, 1171-1175.

SMITH, G. T., ARNOLD, G. W., SARRE, S., ABENSPERG-TRAUN, M. \& STEVEN, D.E. (1996). The effect of habitat fragmentation and livestock grazing on animal communities of gimlet Eucalyptus salubris woodland in the Western Australian wheatbelt. II. Lizards. Journal of Applied Ecology 33, 1302-1310.

STRONG, D. R., MCCOY, E. D. \& REY, J. R. (1977). Time and the number of herbivore species: The pests of sugarcane. Ecology 58, 162-175.

TUCKER, A. D. (1999). Cumulative effects of dams and weirs on freshwater turtles: Fitzroy, Kolan, Burnett and Mary Catchments. Queensland Parks and Wildlife Service \& Queensland Department of Natural Resources, Brisbane.

TURNER, F. B., JENNRICH, R. I. \& WEINTRAUB, J. D. (1969). Home ranges and body size of lizards. Ecology 50, 1076-1080.

VALENTINE, L. E. (2006). Habitat avoidance of an introduced weed by native lizards. Austral Ecology 31, 732-735.

VALENTINE, L. E., ROBERTS, B. \& SCHWARZKOPF, L. (2007). Mechanisms driving avoidance of non-native plants by lizards. Journal of Applied Ecology 44, 228-237.

VAN KAMPEN, T., EMERICK, S. P. \& PARKES, D. (2003). Increasing the survivorship of the Mary River Turtle. Tiaro District of Southeast Queensland October 2002-March 
2003. Greening Australia, Tiaro and District Landcare Group Inc. \& Queensland Parks and Wildlife Service, Brisbane.

VERMEIJ, G. J. (1996). An agenda for invasion biology. Biological Conservation 78, 3-9.

VILA, M., TESSIER, M., SUEHS, C. M., BRUNDU, G., CARTA, L., GALANIDIS, A., LAMBDON, P., MANCA, M., MEDAIL, F., MORAGUES, E., TRAVESET, A., TROUMBIS, A. Y. \& HULME, P. E. (2006). Local and regional assessments of the impacts of plant invaders on vegetation and soil properties of Mediterranean islands. Journal of Biogeography 33, 853-861.

VITOUSEK, P. M. \& WALKER, L. P. (1989). Biological invasions by Myrica faya in Hawaii: plant demography, nitrogen fixation and ecosystem effects. Ecological Monographs 59, 247-265.

VITT, L. J., CALDWELL, J. P., WILBUR, H. M. \& SMITH, D. C. (1990). Amphibians as harbingers of decay. BioScience 40, 418.

VITT, L. J. \& PIANKA, E. R. (2007). Feeding ecology in the natural world. In Lizard Ecology. The Evolutionary Consequences of Foraging Mode (eds S. M. Reilly, L. D. McBrayer \& D. B. Miles), pp 141-172. Cambridge University Press, Cambridge.

WALLACE, H., BADAWY, G. M. I. \& WALLACE, B. M. N. (1999). Amphibian sex determination and sex reversal. Cellular and Molecular Life Sciences 55, 901-909.

WELLS, K. D. (2007). The ecology and behavior of amphibians. University of Chicago Press, Chicago.

WILSON, S. \& SWAN, G. (2008). A complete guide to reptiles of Australia. 2nd edn. New Holland, Sydney. 


\section{FIGURE LEGENDS}

Fig. 1. Three mechanisms determining the impacts of exotic plants on reptiles and amphibians and the role of plant and reptile/amphibian traits. Intensity of response to invasion increases from right to left in relation to plant and reptile/amphibian traits (top arrow). The timeframe for detectable impacts increases from left to right (bottom arrow). 
Table 1. Studies examining the ecological impacts of exotic plants on reptiles and amphibians.

Ecological measures include species richness or abundance. Effect indicates the change in species richness or abundance ( $+=$ increase in abundance or richness, $-=$ decrease, $0=$ no change).

\begin{tabular}{llll}
\hline Taxa & Measure & Effect & Source \\
\hline All reptile species & abundance & - & Braithwaite et al. (1989) \\
All amphibian species & abundance & 0 & Braithwaite et al. (1989) \\
Carlia tetradactyla (lizard) & abundance & + & Fischer et al. (2003) \\
All reptile species & abundance & + & Garden et al. (2007) \\
All lizard species & abundance & - & Griffin et al. (1989) \\
All reptile species & richness & - & Hadden \& Westbroke (1996) \\
All amphibian species & richness & 0 & Hadden \& Westbroke (1996) \\
All lizard species & richness & - & Jellinek et al. (2004) \\
All amphibian species & richness & 0 & Sax (2002) \\
Scincid lizards & richness & - & Smith et al. (1996) \\
All lizard species & abundance & - & Valentine (2006) \\
\hline
\end{tabular}


Table 2. Australian reptile species identified as threatened by exotic plants. Selected reptile traits (native habitat, size, reproductive strategy and diet) and the threatening plant species are listed. SL = shell length; SVL = snout vent length; TL = total length; Generic = general threat from exotic plants with no particular exotic plant species identified. Sources include Cogger (2000), Coutts-Smith \& Downey (2006), Department of Environment and Climate Change (2009), Department of Environment, Water, Heritage and the Arts (2009), and Wilson \& Swan (2008).

\begin{tabular}{|c|c|c|c|c|c|c|}
\hline Family & Species & Native habitat & $\begin{array}{l}\text { Average } \\
\text { body size } \\
(\mathrm{mm})\end{array}$ & $\begin{array}{l}\text { Oviparous (O) } \\
\text { / viviparous } \\
\text { (V) }\end{array}$ & Diet & $\begin{array}{l}\text { Threatening exotic } \\
\text { plants }\end{array}$ \\
\hline Agamidae & $\begin{array}{l}\text { Grassland earless dragon } \\
\text { (Tympanocryptis pinguicolla) }\end{array}$ & $\begin{array}{l}\text { Temperate } \\
\text { grasslands }\end{array}$ & 50 (SVL) & $\mathrm{O}$ & $\begin{array}{l}\text { Small } \\
\text { invertebrates }\end{array}$ & Generic \\
\hline
\end{tabular}




\begin{tabular}{|c|c|c|c|c|c|c|}
\hline \multirow[t]{2}{*}{ Elapidae } & $\begin{array}{l}\text { Dunmall's snake } \\
\text { (Furina dunmalli) }\end{array}$ & $\begin{array}{l}\text { Eucalypt and } \\
\text { Callitris woodland, } \\
\text { brigalow scrub }\end{array}$ & $600(\mathrm{TL})$ & 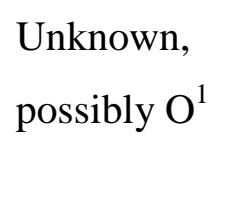 & $\begin{array}{l}\text { Small scincid and } \\
\text { gekkonid lizards }\end{array}$ & Generic \\
\hline & $\begin{array}{l}\text { Little whip snake } \\
\text { (Suta flagellum) }\end{array}$ & $\begin{array}{l}\text { Beneath rocks and } \\
\text { logs in woodland } \\
\text { and grasslands }\end{array}$ & 400 (TL) & $\mathrm{V}$ & $\begin{array}{l}\text { Small scincid } \\
\text { lizards and frogs }\end{array}$ & Generic \\
\hline Gekkonidae & $\begin{array}{l}\text { Lord Howe Island gecko } \\
\text { (Christinus guentheri) }\end{array}$ & $\begin{array}{l}\text { Trees, boulder slopes } \\
\text { and rock faces }\end{array}$ & 80 (SVL) & $\mathrm{O}$ & $\begin{array}{l}\text { Small insects and } \\
\text { arthropods, nectar } \\
\text { of selected tree } \\
\text { species }\end{array}$ & Generic \\
\hline \multirow[t]{3}{*}{ Pygopodidae } & $\begin{array}{l}\text { Pink-tailed worm lizard } \\
\text { (Aprasia parapulchella) }\end{array}$ & $\begin{array}{l}\text { Beneath rocks on } \\
\text { grassy streamside } \\
\text { slopes in woodland }\end{array}$ & $\begin{array}{l}140 \\
(\mathrm{SVL})\end{array}$ & $\mathrm{O}$ & $\begin{array}{l}\text { Ant eggs and } \\
\text { larvae }\end{array}$ & Generic \\
\hline & $\begin{array}{l}\text { Marble-faced delma } \\
\text { (Delma australis) }\end{array}$ & $\begin{array}{l}\text { Beneath rocks and } \\
\text { logs and in Spinifex } \\
\text { (Triodia spp.) in arid } \\
\text { areas }\end{array}$ & 80 (SVL) & $\mathrm{O}$ & $\begin{array}{l}\text { Selected } \\
\text { arthropods, } \\
\text { especially } \\
\text { lepidopteran } \\
\text { larvae }\end{array}$ & Generic \\
\hline & $\begin{array}{l}\text { Striped legless lizard } \\
\text { (Delma impar) }\end{array}$ & $\begin{array}{l}\text { Beneath rocks, logs } \\
\text { and debris in forest } \\
\text { and woodland } \\
\text { habitats }\end{array}$ & 90 (SVL) & $\mathrm{O}$ & $\begin{array}{l}\text { Selected } \\
\text { arthropods, } \\
\text { especially } \\
\text { lepidopteran }\end{array}$ & Generic \\
\hline
\end{tabular}




\begin{tabular}{|c|c|c|c|c|c|c|}
\hline Scincidiae & $\begin{array}{l}\text { Five-clawed worm-skink } \\
\text { (Anomalopus mackayi) }\end{array}$ & $\begin{array}{l}\text { Beneath rocks and } \\
\text { fallen timber in dry } \\
\text { schlerophyll forest, } \\
\text { eucalypt and } \\
\text { Callitris woodland }\end{array}$ & $\begin{array}{l}100 \\
(\mathrm{SVL})\end{array}$ & $\mathrm{O}$ & Unknown & $\begin{array}{l}\text { Coolatai grass } \\
\text { (Hyparrhenia hirta) }\end{array}$ \\
\hline & $\begin{array}{l}\text { Leopard ctenotus } \\
\text { (Ctenotus pantherinus } \\
\text { ocellifer) }\end{array}$ & $\begin{array}{l}\text { Porcupine grasses in } \\
\text { sandy and desert } \\
\text { habitats }\end{array}$ & 90 (SVL) & $\mathrm{O}$ & Small insects & Generic \\
\hline & $\begin{array}{l}\text { Lord Howe Island skink } \\
\text { (Cyclodina lichenigera) }\end{array}$ & $\begin{array}{l}\text { Beneath rocks, } \\
\text { boulders and fallen } \\
\text { timber }\end{array}$ & 80 (SVL) & $\mathrm{O}$ & $\begin{array}{l}\text { Small } \\
\text { invertebrates }\end{array}$ & Generic \\
\hline & $\begin{array}{l}\text { Mallee slender bluetongue } \\
\text { (Cyclodomorphus melanops } \\
\text { elongata) }\end{array}$ & $\begin{array}{l}\text { Spinifex (Triodia } \\
\text { spp.) grasslands, arid } \\
\text { scrubs and heaths }\end{array}$ & $\begin{array}{l}130 \\
(\mathrm{SVL})\end{array}$ & $\mathrm{V}$ & $\begin{array}{l}\text { Invertebrates, } \\
\text { flowers, fleshy } \\
\text { leaves and fruit }\end{array}$ & Generic \\
\hline & $\begin{array}{l}\text { Blue Mountains water skink } \\
\text { (Eulamprus leuraensis) }\end{array}$ & $\begin{array}{l}\text { Riparian and } \\
\text { swampy areas in } \\
\text { montane forests }\end{array}$ & 80 (SVL) & $\mathrm{V}$ & $\begin{array}{l}\text { Insects, some } \\
\text { evidence of } \\
\text { omnivory }\end{array}$ & Generic \\
\hline & $\begin{array}{l}\text { Nangur spiny skink } \\
\text { (Nangura spinosa) }\end{array}$ & $\begin{array}{l}\text { Creek banks in } \\
\text { seasonally dry } \\
\text { rainforest }\end{array}$ & $\begin{array}{l}100 \\
(\mathrm{SVL})\end{array}$ & $\mathrm{V}$ & Invertebrates & $\begin{array}{l}\text { Lantana (Lantana } \\
\text { camara) }\end{array}$ \\
\hline
\end{tabular}

\footnotetext{
${ }^{1}$ Based on closest taxonomically related species.
} 
Table 3. Australian amphibian species identified as threatened by exotic plants. Selected amphibian traits (native habitat, size, parental transport and diet) and the threatening plant species are listed. Generic = general threat from exotic plants with no particular plant species identified.

Sources include Cogger (2000), Coutts-Smith \& Downey (2006), Department of Environment and Climate Change (2009), Department of Environment Water Heritage and the Arts (2009).

\begin{tabular}{|c|c|c|c|c|c|c|}
\hline Family & Species & Native habitat & $\begin{array}{l}\text { Average } \\
\text { body size } \\
(\mathrm{mm})\end{array}$ & $\begin{array}{l}\text { Parental } \\
\text { transport }\end{array}$ & Diet & $\begin{array}{l}\text { Threatening exotic } \\
\text { plants }\end{array}$ \\
\hline \multirow[t]{2}{*}{ Hylidae } & $\begin{array}{l}\text { Green and golden bell frog } \\
\text { (Litoria aurea) }\end{array}$ & $\begin{array}{l}\text { Vegetation within or } \\
\text { at the edges of } \\
\text { permanent water }\end{array}$ & 85 & No & Small frogs & Generic \\
\hline & $\begin{array}{l}\text { Booroolong frog } \\
\text { (Litoria booroolongensis) }\end{array}$ & $\begin{array}{l}\text { Beneath boulders } \\
\text { and debris of } \\
\text { permanent mountain } \\
\text { streams }\end{array}$ & 45 & $\mathrm{~N}$ & Unknown & $\begin{array}{l}\text { Willows } \\
\text { (Salix spp.) }\end{array}$ \\
\hline Myobatrachidae & Giant burrowing frog & Burrows near water & 95 & No & Ground-dwelling & Generic \\
\hline
\end{tabular}




\begin{tabular}{|c|c|c|c|c|c|}
\hline (Heleioporus australiacus) & in sandy soil areas & & & invertebrates & \\
\hline & $\begin{array}{l}\text { with native } \\
\text { vegetation }\end{array}$ & & & & \\
\hline $\begin{array}{l}\text { Fleay’s barred frog } \\
\text { (Mixophyes fleayi) }\end{array}$ & Wet forests & 80 & No & Insects, small frogs & Generic \\
\hline $\begin{array}{l}\text { Southern barred frog } \\
\text { (Mixophyes iteratus) }\end{array}$ & $\begin{array}{l}\text { Leaf litter in } \\
\text { rainforests and } \\
\text { eucalypt forests }\end{array}$ & 115 & No & $\begin{array}{l}\text { Insects, spiders and } \\
\text { small frogs }\end{array}$ & Generic \\
\hline $\begin{array}{l}\text { Northern Corroboree frog } \\
\text { (Pseudophryne pengilleyi) }\end{array}$ & $\begin{array}{l}\text { Beneath leaf litter, } \\
\text { logs and dense } \\
\text { ground cover }\end{array}$ & 30 & No & $\begin{array}{l}\text { Small ants and other } \\
\text { invertebrates }\end{array}$ & $\begin{array}{l}\text { Blackberry } \\
\text { (Rubus fructicosus) }\end{array}$ \\
\hline
\end{tabular}


Figure 1

Large

Plant characteristics

Novel growth form / structure

Large spatial coverage

Reptile/amphibian characteristics

Small body size

Small home range

Habitat specialist

Plant characteristics

Taxonomically distinct from native vegetation

Novel growth form / structure

Large spatial coverage

Reptile/amphibian characteristics

Small body size

Small home range

Herbivorous/omnivorous/insectivorous

Dietary specialist

$\underline{\text { Plant characteristics }}$

Novel growth form / structure

Large spatial coverage

Reptile/amphibian characteristics

Oviparity

No parental transport

Short life span / generation time

Temperature-dependent sex determination

Narrow range of oviposition sites
Responsiveness to invasion of exotic plants

Small

\begin{tabular}{c} 
Mechanism 1 \\
$\begin{array}{c}\text { Changes to habitat structure } / \\
\text { heterogeneity }\end{array}$ \\
\hline
\end{tabular}

Mechanism 2

Alteration of herbivory / predator-

prey interactions

characteristics

Taxonomically similar to native vegetation

Similar growth form / structure

Small spatial coverage

\section{Reptile/amphibian characteristics}

Large body size

Large home range

Predator of vertebrates

Dietary generalist

Plant characteristics

Mechanism 3

Modification of reproductive

success

Similar growth form / structure

Small spatial coverage

Reptile/amphibian characteristics

Viviparity

Parental transport

Longer life span / generation time

Genotypic sex determination

Broad range of oviposition sites 